\title{
MENCEGAH DAN MENGATASI NYERI PUNGGUNG BAWAH (NPB) SELAMA BELAJAR DAN BEKERJA DARI RUMAH
}

\author{
Farahdina Bachtiar ${ }^{1 *}$, Irianto ${ }^{2}$, Condrowati $^{3}$, Agustiyawan $^{4}$, \\ Purnamadyawati ${ }^{5}$, Suci Wahyu Ismiyasa ${ }^{6}$, Heri Wibisono ${ }^{7}$, Andy Sirada ${ }^{8}$ \\ 1,3,4,5,6,7,8 Program Studi Fisioterapi, Fakultas Ilmu Kesehatan, \\ Universitas Pembangunan Nasional Veteran Jakarta \\ ${ }^{2}$ Program Studi Fisioterapi, Fakultas Keperawatan, Universitas Hasanuddin \\ Email Korespondensi: farahdinabachtiar@upnvj.ac.id
}

Disubmit: 17 Oktober $2021 \quad$ Diterima: 4 Desember $2021 \quad$ Diterbitkan: 01 Januari 2022 DOI: https://doi.org/10.33024/jkpm.v1i1.5326

\begin{abstract}
ABSTRAK
Selama Pandemi Covid-19, salah satu gangguan muskuloskeletal yang paling umum dikeluhkan oleh masyarakat adalah nyeri punggung bawah (NPB). Meningkatnya keluhan NPB selama pandemi diduga terjadi akibat peningkatan intensitas dan durasi duduk akibat teleworking atau pembelajaran jarak jauh, kurangnya aktivitas fisik, dan minimnya ketersediaan tempat kerja yang ergonomis di rumah. Oleh karena itu, kegiatan pengabdian kepada masyarakat (PKM) ini bertujuan untuk memberikan pengetahuan dan edukasi kepada masyarakat mengenai cara mencegah dan mengatasi NPB selama belajar dan bekerja dari rumah. Kegiatan ini diselenggarakan secara daring. Sebelum dan setelah pemberian materi, peserta diminta untuk mengisi pre-test dan post-test untuk mengetahui tingkat pengetahuannya mengenai materi yang diberikan. Kegiatan PKM berlangsung selama kurang lebih tiga jam. Pemberian materi dilakukan melalui metode ceramah dan diskusi. Hasil kegiatan ini menunjukkan adanya peningkatan pengetahuan peserta PKM mengenai NPB. Rata-rata skor pengetahuan peserta sebelum pemberian materi adalah 52,65 sedangkan setelah pemberian materi menjadi 84,41. Peserta juga menilai bahwa kegiatan PKM ini telah terselenggara dengan baik dan bermanfaat bagi peserta.
\end{abstract}

Kata Kunci: nyeri punggung bawah; working from home; pembelajaran jarak jauh

\begin{abstract}
During the Covid-19 pandemic, one of the most common musculoskeletal disorders is low back pain (LBP). The increase in LBP during the pandemic may due to the increased intensity and duration of sitting because of teleworking or distance learning, lack of physical activity, as well as the lack of availability of an ergonomic workstation at home. Therefore, this community service activity aims to provide knowledge and educate the community on how to prevent and overcome LBP while studying and working from home. This program was held online. Participants were asked to complete the pre-test and post-test questionnaire to assess their level of knowledge about LBP. The activity lasted for approximately three hours. The methods of this community service were lecture and discussion. The results indicated an increase in the knowledge of participants about LBP. Participants also considered that this community service had been well organized and beneficial for them.
\end{abstract}

Keywords: low back pain; working from home; distance learning 


\section{PENDAHULUAN}

Sejak WHO (World Health Organization atau Badan Kesehatan Dunia) secara resmi mendeklarasikanvirus corona (Covid-19) sebagai pandemi, terjadi perubahan yang cukup signifikan dalam hampir seluruh aspek kehidupan masyarakat di dunia. Salah satu strategi yang diambil pemerintah Indonesia dalam menekan penyebaran Covid-19 adalah dengan menetapkan kebijakan Pembatasan Sosial Berskala Besar (PSBB) (Kemeterian Kesehatan Republik Indonesia, 2020). Masyarakat diminta untuk tetap tinggal di rumah dan melakukan aktivitas seperti belajar, bekerja, dan beribadah dari rumah. Himbauan ini tentunya dapat mencegah terjadinya penularan dan penyebaran Covid-19, namun di sisi lain juga dapat berdampak pada aspek kesehatan lainnya, seperti meningkatnya keluhan muskuloskeletal (Condrowati et al., 2020).

Salah satu keluhan muskuloskeletal yang paling umum dikeluhkan oleh masyarakat selama Pandemi Covid-19 adalah nyeri punggung bawah (NPB). Prevalensi NPB sebelum pandemi adalah $38,8 \%$ dan meningkat menjadi $43,8 \%$ saat pandemi (Šagát et al., 2020). Dalam penelitian tersebut dilaporkan bahwa intensitas NPB juga meningkat secara signifikan selama pandemi. Penelitian yang dilakukan oleh Toprak Celenay et al (2020) menemukan bahwa kasus NPB lebih tinggi pada orang-orang yang bekerja dari rumah dibandingkan dengan mereka yang tetap bekerja di kantor selama Pandemi Covid-19.

Menurut European Guidelines, nyeri punggung bawah (NPB) didefinisikan sebagai "nyeri dan ketidaknyamanan", terlokalisasi di bawah batas kosta dan di atas lipatan gluteal inferior, dengan atau tanpa nyeri hingga ke tungkai (Van Tulder et al., 2006). NPB menyebabkan lebih banyak kecacatan dibandingkan dengan kondisi lainnya (Hoy et al., 2014). Selain itu, hal ini tentu saja akan berdampak pada tingginya biaya pengobatan yang dikeluarkan, menurunkan produktivitas kerja, dan gangguan dalam melakukan aktivitas sehari-hari (Manchikanti et al., 2014).

Meningkatnya keluhan NPB selama Pandemi Covid-19 diperkirakan terjadi akibat peningkatan intensitas penggunaan teknologi untuk pendidikan, komunikasi, dan hiburan selama berada di rumah (Toprak Celenay et al., 2020). Penggunaan teknologi tersebut menyebabkan tingginya durasi duduk yang berdampak pada timbulnya keluhan NPB, karena terjadinya pembebanan berlebih pada daerah tulang belakang (Toprak Celenay et al., 2020). Faktor lain seperti usia antara 35-49 tahun, stress, rendahnya aktivitas fisik, memiliki Indeks Massa Tubuh (IMT) sama dengan atau melebihi 30, dan menjalani teleworking atau pembelajaran jarak jauh dikaitkan dengan tingginya intensitas NPB (Šagát et al., 2020).

Berdasarkan latar belakang di atas, kegiatan Pengabdian kepada Masyarakat (PKM) ini dilakukan untuk memberikan pengetahuan bagi masyarakat mengenai nyeri punggung bawah, pencegahan, dan cara mengatasinya selama belajar dan bekerja dari rumah. Dengan bekal pengetahuan serta edukasi yang diberikan, diharapkan keluhan nyeri punggung bawah yang dialami oleh masyarakat dapat diminimalisasi. 


\section{MASALAH}

Terjadi peningkatan keluhan muskuloskeletal termasuk nyeri punggung bawah (NPB) selama masa Pandemi Covid-19 di Indonesia. Diketahui bahwa terdapat sekitar 45,30\% orang yang mengalami keluhan NPB saat diberlakukannya aturan Pembatasan Sosial Berskala Besar (PSBB) akibat Pandemi Covid-19 (Condrowati et al., 2020). Penurunan aktifitas fisik serta minimnya ketersediaan tempat kerja yang ergonomis di rumah menjadi faktor pemicu terjadinya NPB. Kegiatan ini bertujuan untuk mengedukasi masyarakat, utamanya mereka yang bekerja dan belajar dari rumah mengenai pencegahan dan cara mengatasi NPB.

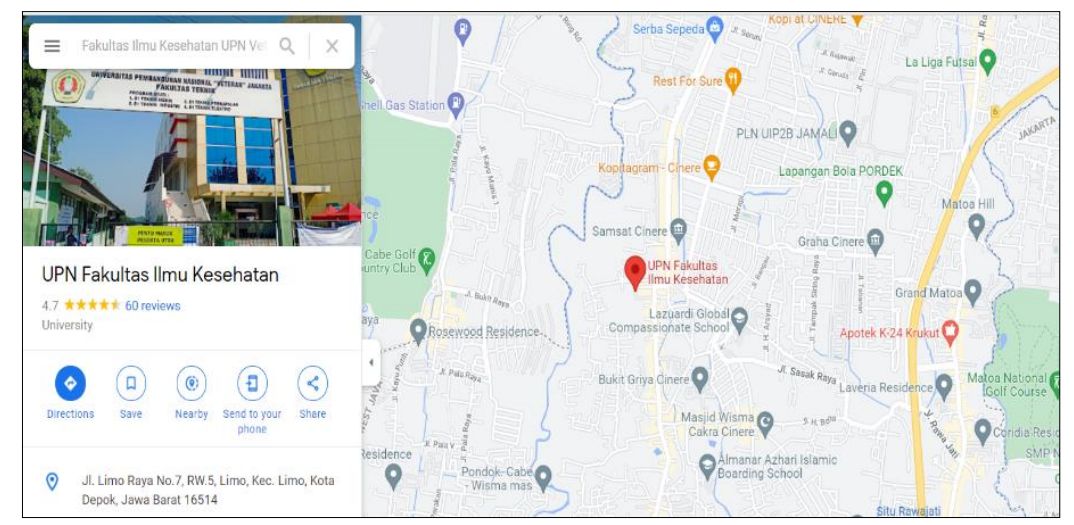

Gambar 1. Peta Lokasi Fakultas Ilmu Kesehatan UPN Veteran Jakarta

\section{METODE}

Metode yang digunakan dalam kegiatan Pengabdian Kepada Masyarakat (PKM) ini adalah berupa penyuluhan dan pemberian edukasi kepada masyarakat mengenai pencegahan dan cara mengatasi nyeri punggung bawah (NPB) selama belajar dan bekerja dari rumah. Sasaran dalam kegiatan pengabdian ini adalah masyarakat, khususnya yang menjalani belajar dan bekerja dari rumah. Adapun tahapan metode dalam kegiatan PKM ini adalah sebagai berikut:

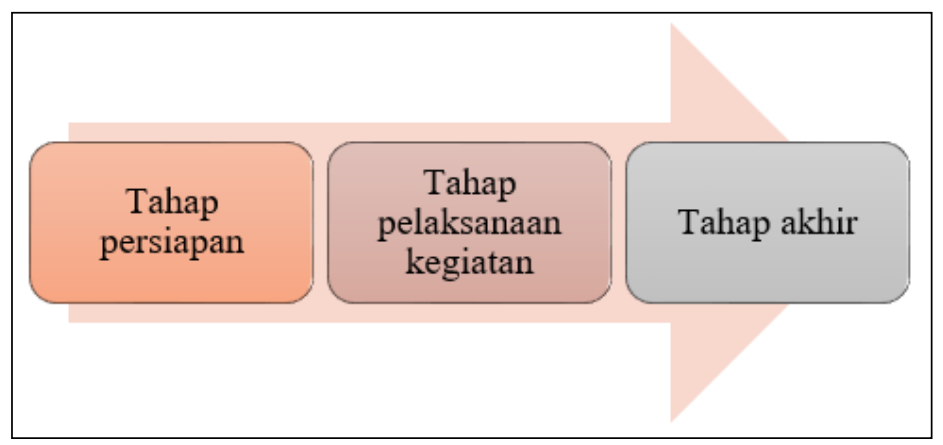

Gambar 2. Tahapan kegiatan PKM

Pada tahap persiapan, kegiatan yang dilakukan berupa pembuatan proposal kegiatan, permohonan izin pelaksanaan kegiatan pengabdian, serta sosialisasi kegiatan melalui flyer yang disebarkan melalui media sosial. Tahap pelaksanaan kegiatan meliputi pemberian pre-test untuk mengetahui pengetahuan peserta mengenai NPB, kemudian dilanjutkan dengan penyuluhan 
dan pemberian edukasi, dan diakhir kegiatan peserta diminta untuk mengisi posttest sebagai evaluasi. Kegiatan diselenggarakan secara daring dengan menggunakan media zoom meeting. Peserta yang hadir dibekali pengetahuan diantaranya: 1) pengertian NPB; 2) prevalensi atau insiden NPB selama Pandemi Covid-19; 3) desain tempat kerja yang ergonomis di rumah; serta 4) latihanlatihan yang dapat dilakukan secara mandiri di rumah untuk mencegah dan mengatasi NPB. Setelah pelaksanaan kegiatan, tahap akhir yang dilakukan adalah pengolahan data, pembuatan laporan hasil kegiatan, dan publikasi hasil kegiatan pengabdian kepada masyarakat.

\section{HASIL DAN PEMBAHASAN}

Kegiatan Pengabdian kepada Masyarakat (PKM) ini mengangkat tema "Mencegah dan Mengatasi Nyeri Punggung Bawah (NPB) selama Belajar dan Bekerja dari Rumah". Kegiatan ini dilakukan secara daring pada tanggal 5 Juni 2021. Terdapat 68 peserta yang terdiri dari 11 (16,20\%) laki-laki dan 57 (83,80\%) perempuan yang mengisi pre-test dan post-test secara lengkap. Peserta PKM didominasi oleh pelajar, berusia rata-rata 19 tahun $(S D=0,76)$. Adapun tujuan kegiatan PKM ini dilakukan adalah untuk memberikan pengetahuan bagi para peserta mengenai pencegahan dan cara mengatasi nyeri punggung bawah (NPB) selama belajar dan bekerja dari rumah di masa Pandemi Covid-19.
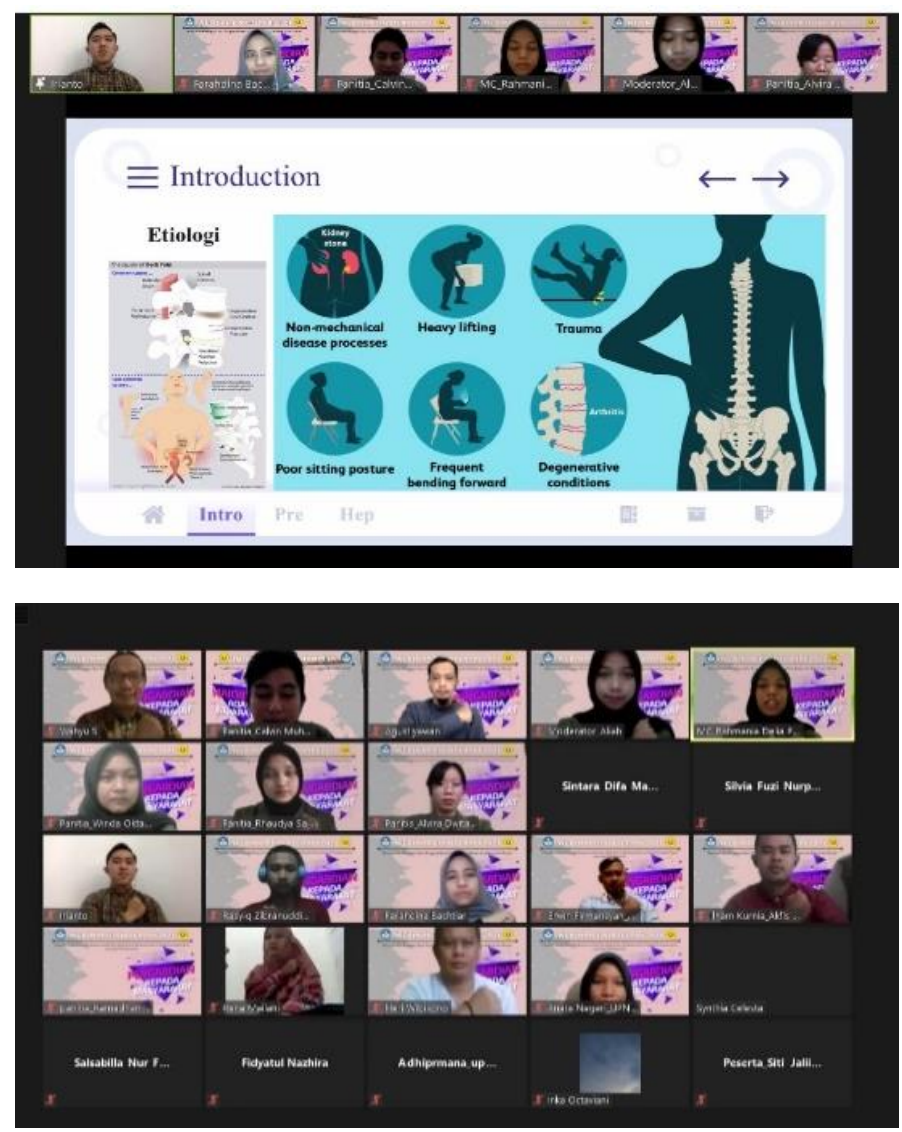

Gambar 3. Pelaksanaan kegiatan PKM yang dilakukan secara daring 
Sebelum penyampaian materi, kegiatan PKM diawali dengan pengisian kuesioner oleh peserta dengan menggunakan google form. Kuesioner berisi pertanyaan mengenai keluhan nyeri punggung bawah (NPB) peserta selama belajar dan bekerja dari rumah serta pertanyaan yang berkaitan dengan pengetahuan mengenai NPB. Berdasarkan data, diketahui bahwa mayoritas peserta PKM mengalami keluhan NPB, yaitu 55 (80,90\%) peserta (Gambar 4).

Tingkat pengetahuan peserta PKM mengenai nyeri punggung bawah diukur dengan menggunakan kuesioner yang dilakukan sebelum dan setelah pemberian materi. Berdasarkan hasil uji paired t-test, terdapat perbedaan skor pengetahuan yang signifikan antara sebelum dan setelah penyuluhan dan pemberian edukasi mengenai NPB, yaitu $p=0,001$ atau $p<0,05$. Rata-rata skor pengetahuan peserta sebelum pemberian materi adalah 52,65 ( $S D=21,55)$, sedangkan setelah pemberian materi menjadi 84,41 ( $S D=22,08)$ (Gambar 5).

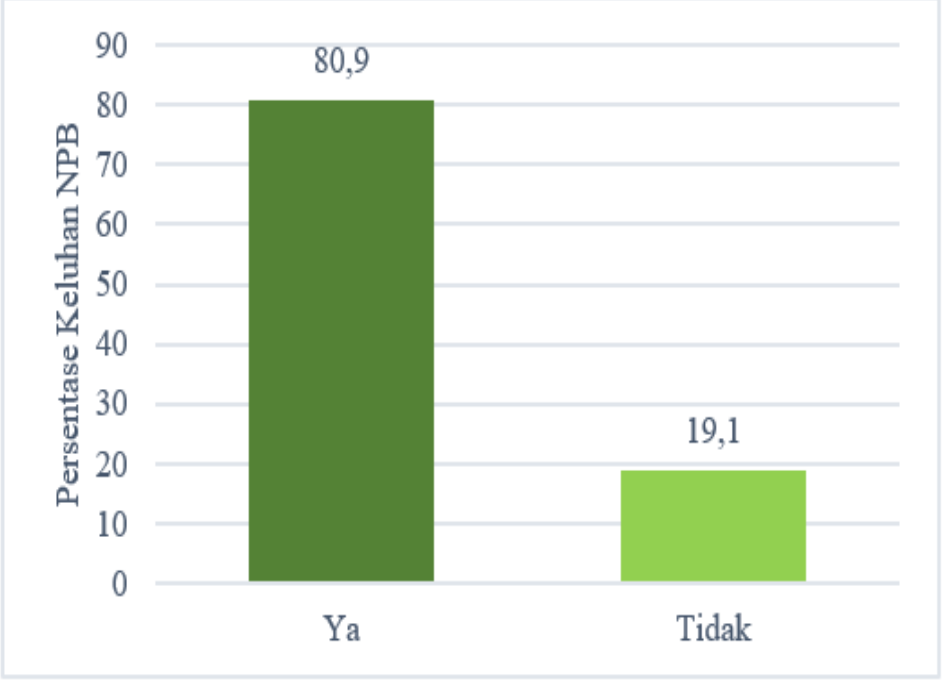

Gambar 4. Persentase Keluhan Nyeri Punggung Bawah (NPB)

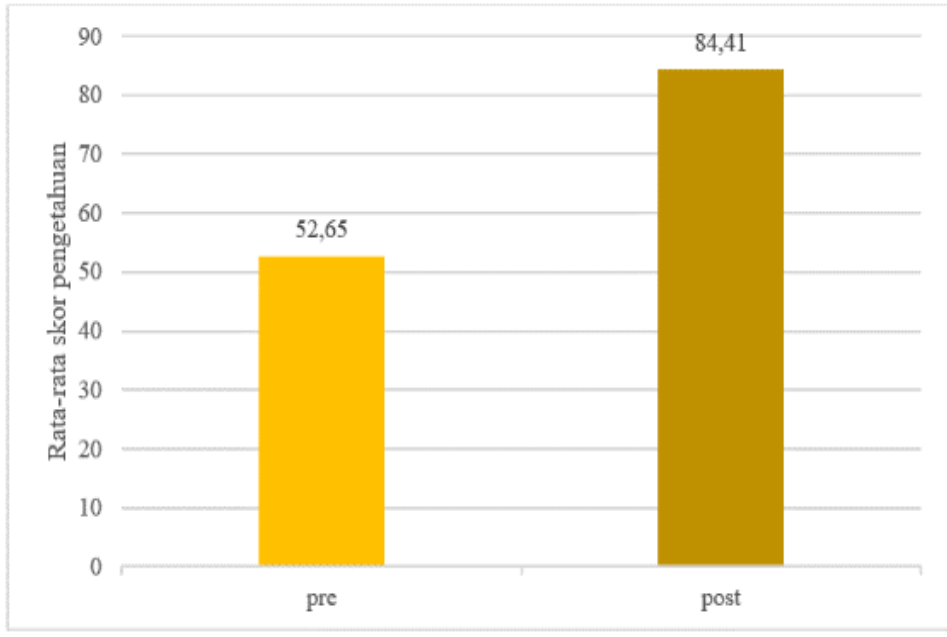

Gambar 5. Skor pengetahuan peserta PKM sebelum dan setelah pemberian materi 
Kegiatan PKM berlangsung selama kurang lebih 3 jam. Peserta diberikan materi pengenalan nyeri punggung bawah, cara mencegah, dan mengatasinya. Pemberian materi dilakukan melalui metode ceramah dan diskusi. Meskipun kegiatan dilakukan secara daring, peserta nampak antusias mengikuti kegiatan PKM, ditunjukkan dengan aktif bertanya setelah sesi ceramah. Selain itu, hasil evaluasi kegiatan PKM juga menunjukkan bahwa sebagian besar peserta menilai bahwa kegiatan PKM ini sangat bermanfaat (Tabel 1).

Tabel 1. Evaluasi Pelaksanaan PKM

\begin{tabular}{clccc}
\hline No & \multicolumn{1}{c}{ Pertanyaan } & $\begin{array}{c}\text { Tidak } \\
\text { setuju }\end{array}$ & Setuju & $\begin{array}{c}\text { Sangat } \\
\text { setuju }\end{array}$ \\
\hline 1 & $\begin{array}{l}\text { Kegiatan terselenggara tepat } \\
\text { waktu dan berjalan lancar }\end{array}$ & 0 & $37(54,40 \%)$ & $31(45,60 \%)$ \\
\hline 2 & Kegiatan sesuai dengan tema & 0 & $9(13,20 \%)$ & $59(86,80 \%)$ \\
\hline 3 & $\begin{array}{l}\text { Narasumber menyampaikan } \\
\text { materinya sangat baik dan mudah } \\
\text { dipahami }\end{array}$ & 0 & $16(23,50 \%)$ & $52(76,50 \%)$ \\
\hline 4 & $\begin{array}{l}\text { Sesi tanya jawab berjalan dengan } \\
\text { efektif dan narasumber } \\
\text { memberikan jawaban dengan } \\
\text { jelas dan mudah dimengerti }\end{array}$ & 0 & $19(27,90 \%)$ & $49(72,10 \%)$ \\
\hline 5 & Kegiatan ini bermanfaat bagi saya & 0 & $24(35,30 \%)$ & $44(64,70 \%)$ \\
\hline
\end{tabular}

Selama masa Pandemi Covid-19, terjadi peningkatan keluhan muskuloskeletal termasuk nyeri punggung bawah (NPB). Penelitian yang dilakukan oleh Šagát et al (2020) menemukan bahwa terjadi peningkatan kasus NPB antara sebelum dan saat Pandemi Covid-19 di Riyadh, Arab Saudi. Prevalensi NPB sebelum pandemi adalah $38,80 \%$ dan menjadi $43,80 \%$ saat pandemi. Di Indonesia, diketahui bahwa terdapat sekitar $45,30 \%$ orang yang mengalami keluhan NPB saat diberlakukannya aturan Pembatasan Sosial Berskala Besar (PSBB) akibat Pandemi Covid-19 (Condrowati et al., 2020).

Sejak Pandemi Covid-19, terjadi pembatasan mobilitas masyarakat di seluruh dunia, termasuk Indonesia. Hal ini tentunya membawa dampak positif karena dapat mengurangi penularan dan penyebaran Covid-19. Namun, pemberlakuan aturan Working from Home (WFH) atau bekerja dari rumah bagi pegawai serta Pembelajaran Jarak Jauh (PJJ) bagi pelajar juga memiliki dampak negatif jika ditinjau dari segi kesehatan.

Penurunan aktivitas fisik, desain tempat kerja yang tidak ergonomis, serta peningkatan durasi kerja atau duduk dapat menyebabkan timbulnya keluhan muskuloskeletal (gangguan otot dan tulang). Berdasarkan hasil penelitian sebelumnya, diketahui bahwa sebagian besar masyarakat (45\%) melakukan pertemuan virtual melalui berbagai aplikasi video konferensi, pembelajaran online (29\%), bekerja melalui percakapan telepon dan email (15\%) atau pengajaran online $(6 \%)$ (Suresh, 2020). Penelitian ini juga menemukan bahwa 
pada umumnya ruang kerja di rumah tidak dirancang secara efisien atau tidak sesuai dengan kebutuhan ruang kerja seperti di kantor.

Selain itu, terdapat hubungan yang bermakna antara lama duduk terhadap keluhan nyeri punggung bawah pada mahasiswa saat pembelajaran jarak jauh akibat Pandemi Covid-19 (Hutasuhut et al., 2021). Kurangnya aktivitas fisik juga menjadi faktor risiko terjadinya nyeri punggung kronis. Individu yang melakukan aktivitas fisik dengan intensitas sedang memiliki risiko NPB 10\% lebih rendah dibandingkan dengan mereka yang melakukan aktivitas fisik dengan intensitas rendah (Alzahrani et al., 2019). Selama pemberlakuan PSBB di Indonesia, diketahui bahwa rata-rata masyarakat melakukan aktivitas fisik dengan intensitas rendah (45.6\%) (Bachtiar et al., 2020).

\section{KESIMPULAN}

Kegiatan PKM ini diharapkan dapat menambah pengetahuan dan wawasan masyarakat mengenai cara mencegah dan mengatasi nyeri punggung bawah dengan melakukan desain tempat kerja yang ergonomis serta mengaplikasikan latihan-latihan sederhana yang dapat dilakukan secara mandiri di rumah.

\section{DAFTAR PUSTAKA}

Alzahrani, H., Mackey, M., Stamatakis, E., Zadro, J. R., \& Shirley, D. (2019). The association between physical activity and low back pain: a systematic review and meta-analysis of observational studies. Scientific Reports, 9(1), 1-10. https: / / doi.org/10.1038/s41598-019-44664-8

Bachtiar, F., Condrowati, Utari, D., \& Maharani, F. T. (2020). Physical Activity Levels of Adults During Covid-19 Quarantine in Indonesia: A Cross-Sectional Descriptive Study. 30(lchd), 267-273. https://doi.org/10.2991/ahsr.k.201125.047

Condrowati, Bachtiar, F., Maharani, F. T., \& Utari, D. (2020). Musculoskeletal Disorder of Workers During Work From Home on Covid-19 Pandemic: A Descriptive Study. 30(Ichd), 153-160. https://doi.org/10.2991/ahsr.k.201125.025

Hoy, D., March, L., Brooks, P., Blyth, F., Woolf, A., Bain, C., Williams, G., Smith, E., Vos, T., Barendregt, J., Murray, C., Burstein, R., \& Buchbinder, R. (2014). The global burden of low back pain: Estimates from the Global Burden of Disease 2010 study. Annals of the Rheumatic Diseases, 73(6), 968974. https://doi.org/10.1136/annrheumdis-2013-204428

Hutasuhut, R. O., Lintong, F., \& Rumampuk, J. F. (2021). Hubungan Lama Duduk Terhadap Keluhan Nyeri Punggung Bawah. Jurnal E-Biomedik, 9(2), 160-165. https://doi.org/10.35790/ebm.v9i2.31808

Indonesia, R. (2020). Peraturan Menteri Kesehatan Republik Indonesia Nomor 9 Tahun 2020 Tentang Pedoman Pembatasan Sosial Berskala Besar Dalam Rangka Percepatan Penanganan Corona Virus Disease 2019 (Covid19). Jakarta: Kemeterian Kesehatan Republik Indonesia.

Manchikanti, L., Singh, V., Falco, F. J. E., Benyamin, R. M., \& Hirsch, J. A. (2014). Epidemiology of low back pain in Adults. Neuromodulation, 17(S2), 3-10. https://doi.org/10.1111/ner.12018

Šagát, P., Bartík, P., González, P. P., Tohănean, D. I., \& Knjaz, D. (2020). Impact of COVID-19quarantine on low back pain intensity, prevalence, and associated risk factors among adult citizens residing in riyadh (Saudi Arabia): 
A cross-sectional study. International Journal of Environmental Research and Public Health, 17(19), 1-13. https://doi.org/10.3390/ijerph17197302

Suresh, G. (2020). Workspace and postural challenges in Work from Home (WFH) Scenario. International Journal of Grid and Distributed Computing, 13(2), 12-20.

Toprak Celenay, S., Karaaslan, Y., Mete, O., \& Ozer Kaya, D. (2020). Coronaphobia, musculoskeletal pain, and sleep quality in stay-at home and continued-working persons during the 3-month Covid-19 pandemic lockdown in Turkey. Chronobiology International, 37(12), 1778-1785. https://doi.org/10.1080/07420528.2020.1815759

Van Tulder, M., Becker, A., Bekkering, T., Breen, A., Del Real, M. T. G., Hutchinson, A., Koes, B., Laerum, E., \& Malmivaara, A. (2006). Chapter 3: European guidelines for the management of acute nonspecific low back pain in primary care. European Spine Journal, 15(SUPPL. 2), 169-191. https: / / doi.org/10.1007/s00586-006-1071-2

World Health Organization (WHO). Diakses dari https://www.who.int/directorgeneral/speeches/detail/who-director-general-s-opening-remarks-at-themedia-briefing-on-covid-19---11-march-2020 